\title{
SISTEM INFORMASI PEMESANAN PAKET WISATA NAGARI TARUSAN KABUPATEN PESISIR SELATAN
}

\author{
Nofriadiman ${ }^{1}$ \\ ${ }^{1}$ Program Studi Sistem Informasi \\ Sekolah Tinggi Teknologi Industri (STTIND) Padang
}

\begin{abstract}
Nagari Tarusan located in the Kabupaten Pesisir Selatan which has many tourist resorts, culinary and traditions still hold in high regard. The tourist resorts has a great potential to be developed, but a high potential is still not supported by ease of access to reach the tourist site, where the number and frequency of departure public transportation to tourist objects that exist in the region is still low and not optimal. Making the reservation website Nagari Tarusan tour packages will provide convenience for the people of Indonesia and the world. With the tour package booking website Nagari Tarusan will promote local economies and provide additional income for the Kabupaten Pesisir Selatan budget later.
\end{abstract}

Keywords : Website, Tourism

\section{PENDAHULUAN}

\subsection{Latar Belakang Masalah}

Pariwisata adalah kegiatan dinamis yang melibatkan banyak manusia serta menghidupkan berbagai bidang usaha. Di era globalisasi saat ini, sektor pariwisata akan menjadi pendorong utama perekonomian dunia dan menjadi industri yang maju. Pariwisata akan memberikan banyak pemasukan bagi daerah yang sadar akan potensinya terhadap sektor pariwisata. Dengan berkembanganya pariwisata, akan mendongkrak sektor yang lain, seperti: kunjungan wisatawan, ekonomi kreatif, membuka kesempatan kerja, dan mengurangi pengangguran. Peranan teknologi komputer dalam hal ini yaitu meningkatkan daya tarik kunjungan wisatawan, baik wisatawan lokal maupun wisatawan internasional.

Potensi yang dimiliki oleh Nagari Tarusan, antara lain obyek wisata Pantai Batu Kalang dan kawasan wisata Mandeh yang memiliki keindahan alam dan keindahan pantai dan menjadi salah satu destinasi bagi para pencinta keindahan alam di seluruh wilayah Indonesia dan Mancanegara. Serta berbagai macam kuliner yang nikmat dan tradisi yang masih di junjung tinggi, namun potensi yang tinggi tersebut masih kurang didukung oleh kemudahan akses untuk mencapai lokasi wisata tersebut, dimana jumlah dan frekuensi keberangkatan transportasi umum menuju obyek-obyek wisata yang ada masih rendah dan belum optimal dan belum adanya website tentang pemesanan paket wisata di daerah tersebut, serta kurangnya informasi dan belum terorganisasinya tentang penginapan dan transportasi, obyek-obyek wisata, kuliner dan tradisi Nagari Tarusan di dunia maya. Dari keterangan di atas maka perlu adanya sebuah website untuk memberikan informasi tentang penginapan dan transportasi, obyek-obyek wisata, kuliner dan tradisi yang lebih baik serta akurat.

Berdasarkan uraian diatas, maka penulis tertarik untuk mencoba memberikan suatu gagasan berupa sebuah sistem yang mudahmudahan akan bisa memajukan wilayah Nagari Tarusan dan lebih baik nantinya, maka penulis tertarik untuk mengangkat sebuah judul "Sistem Informasi Pemesanan Paket Wisata Nagari Tarusan Kabupaten Pesisir Selatan".

\subsection{Identifikasi Masalah}

Berdasarkan latar belakang masalah pada Nagari Tarusan, maka penulis dapat mengidentifikasi masalah sebagai berikut :

1. Kurangnya informasi dan belum terorganisasinya tentang penginapan dan transportasi, obyek-obyek wisata, kuliner dan tradisi Nagari Tarusan di dunia maya.

2. Potensi pariwisata Nagari Tarusan belum dikelola dengan baik. 


\subsection{Rumusan Masalah}

Berdasarkan latar belakang masalah yang telah dikemukakan di atas, maka fokus permasalahan yang akan dibahas dalam penelitian ini meliputi :

1. Bagaimana membuat website pemesanan paket wisata di Nagari Tarusan?

2. Bagaimana memperkenalkan obyek-obyek wisata, kuliner, dan tradisi Nagari Tarusan dengan bantuan website?

\subsection{Tujuan Penelitian}

Tujuan yang dibahas dalam sistem informasi pemesanan paket wisata Nagari Tarusan, yaitu : Membuat website pemesanan paket wisata Nagari Tarusan.

\section{TINJAUAN PUSTAKA}

\subsection{Landasan Teori}

Pada landasan teori ini kita harus mengetahui apa-apa saja yang akan dibahas diantaranya yaitu:

\subsubsection{Konsep Sistem Informasi}

Sebelum membangun sebuah sistem, terlebih dahulu kita harus mengenal teori mengenai konsep dari sistem informasi tersebut.

\subsubsection{Pengertian Sistem}

Menurut Sutabri (2012), sistem dapat diartikan sebagai suatu kumpulan atau himpunan dari unsur, komponen, atau variable yang terorganisi,saling berinteraksi, saling bergantung satu sama sama lain dan terpadu.

\subsubsection{Karakteristik Sistem}

Menurut Sutabri (2012), suatu sistem mempunyai karakteristik. Karakteristik sistem sebagai berikut :

1. Komponen Sistem (Components). Sejumlah komponen yang saling berinteraksi yang saling bekerja sama membentuk satu kesatuan.

2. Batasan Sistem (Boundary). Daerah yang membatasi suatu sistem dengan sistem yang lainnya atau dengan lingkungan luarnya.

3. Lingkungan Luar Sistem (Environments). Apapun diluar batas sistem yang mempengaruhi operasi sistem.

4. Penghubung Sistem (Interface). Media yang menghubungkan sistem dengan subsistem lain.

5. Masukan Sistem (Input). Energi yang di masukkan ke dalam sistem yang dapat berupa pemeliharaan (maintenance) dan sinyal (signal input).
6. Keluaran Sistem (Output). Hasil energi yang diolah dan diklasifikasikn menjadi keluaran yag berguna.

7. Pengolah Sistem (Proses). Suatu sistem dapat mempunyai suatu proses yang akan mengubah masukan menjadi keluaran.

8. Sasaran Sistem (Objective). Suatu sistem memiliki tujuan dan sasaran yang pasti dan bersifat deterministic.

\subsubsection{Pengertian Sistem Informasi}

Menurut Sutabri (2012), sistem informasi adalah suatu sistem didalam suatu organisasi yang mempertemukan kebutuhan pengolahan transaksi harian yang mendukung fungsi operasi organisasi yang bersifat manajerial dengan kegiatan strategi dari suatu organisasi untuk dapat menyediakan kepada pihak luar tertentu dengan laporan-laporan yang diperlukan.

\subsubsection{Perancangan Sistem}

Dalam merancang sebuah sistem informasi maka kita dapat menggunakan beberapa alat bantu untuk memudahkan dalam perancangan serta memudahkan untuk mengerti bagaimana sebuah sistem informasi tersebut berjalan, yaitu sebagai berikut :

\subsubsection{Unified Modelling Language (UML)} Menurut Irwan Yusti (2012), Metoda Unified Modelling Language (UML) untuk membuat aplikasi perangkat lunak dan membangun perangkat keras yang mendukung kerja dari perangkat lunak yang membahas hubungan antar objek, inheritance, dan diagram-diagram yang digunakan dalam UML. Model-model itu dapat dikelompokkan berdasarkan sifatnya yaitu statis atau dinamis. Jenis diagram itu antara lain

1. Diagram kelas (Class Diagram)

Bersifat statis, diagram kelas bukan hanya digunakan untuk visualisasi, menguraikan dan dokumentasi aspek yang berbeda dari sebuah sistem, tetapi juga untuk membangun kode (executable code) aplikasi perangkat lunak. Diagram kelas digunakan secara luas dalam sistem model orientasi objek karena satu-satunya diagram UML yang dapat dipetakan secara langsung dengan bahasa orientasi objek.

2. Diagram objek (Object Diagram)

Bersifat statis. Diagram objek merupakan cuplikan (snapshot) sistem pada saat tertentu. Diagram objek digunakan untuk 
memandang satu set objek dan hubungan mereka sebagai suatu kejadian. Diagram objek lebih dekat pada prilaku sistem yang nyata sehingga diagram objek dapat digunakan untuk menangkap pandangan yang statis suatu sistem pada saat tertentu.

3. Diagram use-case (Usecase Diagram)

Bersifat statis. Diagram usecase adalah diagram yang melihat dari sudut pandang statis dari kelas dan menunjukan bagaimana sistem dan kelas berubah setiap waktu. Agen internal dan eksternal dalam usecase dikenal dengan aktor.

4. Diagram statechart (Statechart Diagram).

Bersifat dinamis. Diagram ini menggambarkan transisi dan perubahan keadaan (dari sebuah status ke status lain) sebuah objek pada sistem akibat stimuli yang diterimanya mulai dari awal hingga selesai.

5. Diagram sequence (Sequence Diagram) Bersifat dinamis. Diagram ini menggambarkan interaksi antar-antar objek di dalam dan di sekitar sistem (termasuk pengguna, display dan sebaginya) berupa pesan yang di gambarkan terhadap waktu.

7. Diagram aktivitas (Activity Diagram).

Bersifat dinamis. Diagram ini menggambarkan aliran aktifitas dalam sistem yang sedang di rancang yaitu bagaimana masing-masing aliran berawal, pilihan (decision) yang mungkin terjadi dan bagaimana akhir dari aktifitas tersebut.

8. Diagram kolaborasi (Collaboration Diagram)

Bersifat dinamis. Diagram ini menunjukan pengiriman pesan antara satu objek dengan yang lain. Status sebuah objek dilambangkan dengan persegi empat.

9. Diagram komponen (Component diagram) Bersifat statis. Diagram komponen adalah pandangan berbeda dalam prilaku alami sistem, diagram ini digunakan untuk model aspek fisik dari sistem. Yang dimaksud dengan aspek fisik adalah unsurunsur seperti executables, libraries, files, documents dan lain-lain yang terletak dalam titik sambung (node). Jadi diagram komponen digunakan untuk visualisasi organisasi dan hubungan antara komponen dalam sistem.

10. Diagram deployment (Deployment diagram).
Bersifat statis. Diagram ini mengambarkan topologi fisik komponen suatu sistem dimana perangkat lunak dikembangkan.

\section{Manfaat Unified Modeling Language \\ (UML)}

1. Menggambarkan batasan sistem dan fungsi-fungsi sistem secara umum, dibuat dengan use case dan actor.

2. Menggambarkanlah kegiatan atau proses bisnis yang dilaksanakan secara umum, dibuat dengan interaction diagram.

3. Menggambarkan reresentasi struktur static sebuah sistem dalam bentuk class diagram.

4. Membuat model behavior "yang menggambarkan kebiasaan atau sifat sebuah sistem" dengan statetransition diagram.

5. Menyatakan arsitektur implementasi fisik menggunakan component dan development diagram.

6. Kesalahan dalam prosedur pengolahan (misal: kesalahan progam aplikasi komputer yang digunakan.

7. Menyampaikan atau memperluas fungsionaliti dengan stereotypes

\section{Klasifikasi Unified Modeling Language} (UML)

Menurut Nugroho (2010), "bahwa pengklasifikasian pada prinsipnya merupakan konsep diskret dalam model yang memiliki identitas, state, perilaku, serta relasi dengan pengklasifikasian mencakup didalamnya kelas, interface, serta tipe data. Jenis lain dalam pengklasifikasian mencakup didalamnya konsep-konsep perilaku, sesuatu dalam lingkungan saat aplikasi dijalankan (runtime environment), atau struktur-struktur yang berkaitan dengan tahap implementasinya. Pengklasifikasian disini mencakup didalamnya Use Case, Actor, Komponen, Simpul (model) serta subsistem."

- Aktor (Actor)

Menggambarkan semua objek diluar sistem (bukan hanya penggunaan sistem/ perangkat lunak) yang berinteraksi dengan sistem yang dikembangkan.

- Use Case

Menggambarkan fungsionalitas yang dimiliki sistem.

- Kelas (Class)

Menggambarkan konsep dasar pemodelan sistem. 
- Subsistem (Subsystem)

Menggambarkan paket spesifikasi serta implementasi.

- Komponen (Component)

Menggambarkan bagian-bagian fisik sistem/ perangkat lunak yang dikembangkan.

- Antar Muka (Interface). Menggambarkan antar muka pengiriman pesan (message) antar pengklasifikasian.

- Simpul (Node). Menggambarkan sumber daya komputasional yang digunakan oleh sistem.

\subsubsection{Hypertext Markup Language (HTML)}

Menurut Alexander F.K Sibero (2011), HTML atau dengan singkatan Hyper Text Markup Language adalah bahasa pemograman yang digunakan dalam web sebagai bahasa untuk pertukaran dokumen web. Struktur HTML terdiri dari tag pembuka dan tag penutup. Contoh struktur dokumen HTML sebagai berikut:

$<$ html >

$$
\begin{aligned}
& <\text { head }> \\
& <\text { title }></ \text { title }> \\
& <\text { head }> \\
& <\text { body }>\text { </body }>
\end{aligned}
$$

$</$ html $>$

\subsubsection{PHP (Hypertext Preprocessor)}

Menurut Alexander F.K. Sibero (2011), PHP adalah pemograman intrepreter yaitu proses penerjemahan source code menjadi kode mesin yang dimengerti komputer secara langsung pada saat source code dijalankan. PHP adalah singkatan dari Hypertext Preprocessor. PHP disebut sebagai Server Side Programming dikarenakan seluruh prosesnya dijalankan pada server. Script PHP yang dibuat harus tersimpan dalam sebuah server dan dieksekusi atau diproses dalam server tersebut. Dengan menggunakan PHP, sebuah halaman web akan lebih interaktif dan dinamis. PHP tidak dapat dijalankan tanpa menggunakan software pendukung yang bekerja di komputer lokal. Software pendukung yang harus di instalasi, yaitu Apache, PHP, phpMyAdmin, dan database MySQL. Software pendukung ini terdapat dalam sebuah paket software, seperti Xampp dan Appserver.

\subsubsection{MySQL}

Menurut Alexander F.K Sibero (2011), MySQL adalah suatu RDBMS (Relational Database Management System) yaitu sistem aplikasi yang menjalankan fungsi pengolahan data. MySQL dikembangkan oleh MySQL AB yang kemudian diakuisisi Sun Microsystem dan terakhir dikelola oleh Oracle Coorporation

\subsubsection{Basis Data}

Basis data adalah kumpulan data yang saling berhubungan, yang diatur sedemikian rupa sehingga berkaitan dengan struktur dan kebutuhan dari suatu perusahaan/organisasi, serta digunakan oleh lebih dari satu orang dan lebih dari satu aplikasi.

\subsubsection{Macromedia Dreamweaver 8}

Dreamweaver adalah sebuah HTML editor profesional untuk mendesain web secara visual dan mengelola situs atau halaman web. Saat ini terdapat software dari kelompok adobe yang belakangan banyak digunakan untuk mendesain suatu situs web. Pada Dreamweaver 8 , terdapat beberapa kemampuan bukan hanya sebagai software untuk desain web saja tetapi juga untuk menyunting kode serta pembuatan aplikasi web dengan menggunakan berbagai jenis bahasa pemrograman web, antara lain: JPS, PHP, ASP, dan Cold Fusion.

\subsubsection{XAMPP}

XAMPP adalah perangkat lunak bebas yang mendukung banyak sistem operasi, merupakan kompilasi dari beberapa program. Fungsinya adalah sebagai server yang berdiri sendiri (localhost), yang terdiri atas program Apache HTTP Server, MySQL database, dan penerjemah bahasa yang ditulis dengan bahasa pemrograman PHP dan Perl. Nama XAMPP merupakan singkatan dari $\mathrm{X}$ (empat sistem operasi apapun), Apache, MySQL, PHP dan Perl. Program ini tersedia dalam GNU General Public License dan bebas, merupakan web server yang mudah digunakan yang dapat melayani tampilan halaman web yang dinamis.

\subsubsection{Website}

Menurut Janner (2010), Web adalah sebuah sistem dengan informasi yang disajikan dalam bentuk teks, gambar, suara, dan lainnya yang tersimpan dalam sebuah server web internet yang disajikan dalam bentuk hypertext. Informasi web pada umumnya ditulis dalam format HTML. Interaksi web 
dibagi dalam 3 langkah yaitu permintaan, pemrosesan, dan jawaban aplikasi web terbagi dalam 3 jenis dokumen yaitu:

- Dokumen Web Statis

Aplikasi web statis tidak berinteraksi dengan pengunjung. Tujuannya hanya untuk berbagi dan distribusi informasi pada publik. Contoh web statis adalah website pribadi/website personal.

- Dokumen Web Dinamis

Aplikasi web interaktif sederhana tidak seperti web statis yang tidak berinteraksi dengan pengunjung, sebaliknya, aplikasi web interaktif sederhana mengijinkan pengunjung untuk dapat bertukar informasi dengan pemilik web.

- Sistem Basis Data Berbasis Web yang Kompleks

Sistem basis data berbasis web menangani transaksi bisnis online yang modern. Aplikasi ini memungkinkan aplikasi java berjalan pada sisi client, namun kode dapat secara otomatis meminta layanan ke server untuk menjalankan operasi.

\subsection{Kerangka Konseptual}

Adapun kerangka konseptual dalam penyusunan laporan penelitian ini terdiri dari tiga bagian diantaranya : Input, Proses dan Output.

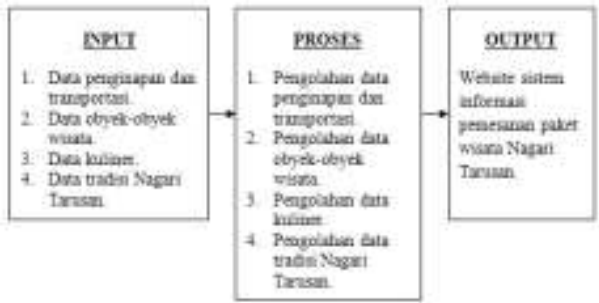

Gambar 2.1 Kerangka Konseptual

\section{METODOLOGI PENELITIAN}

\subsection{Jenis Penelitian}

Jenis penelitian yang peneliti lakukan adalah penelitian terapan. Hasil penelitian tersebut tidak perlu sebagai suatu penemuan baru, tetapi merupakan aplikasi baru dari penelitian yang telah ada dan bisa bermanfaat bagi kemajuan pariwisata Nagari Tarusan.

\subsection{Lokasi Penelitian}

\subsubsection{Tempat Penelitian}

Penelitian dilakukan di Nagari Tarusan yang berlokasi di Kabupaten Pesisir Selatan, Sumatera Barat.

\subsubsection{Waktu Penelitian}

Waktu penelitian dilakukan pada bulan November 2015.

\subsection{Kerangka Metodologi}

Untuk memperjelas arah penelitian ini, dapat dilihat pada gambar kerangka metodologi berikut ini :

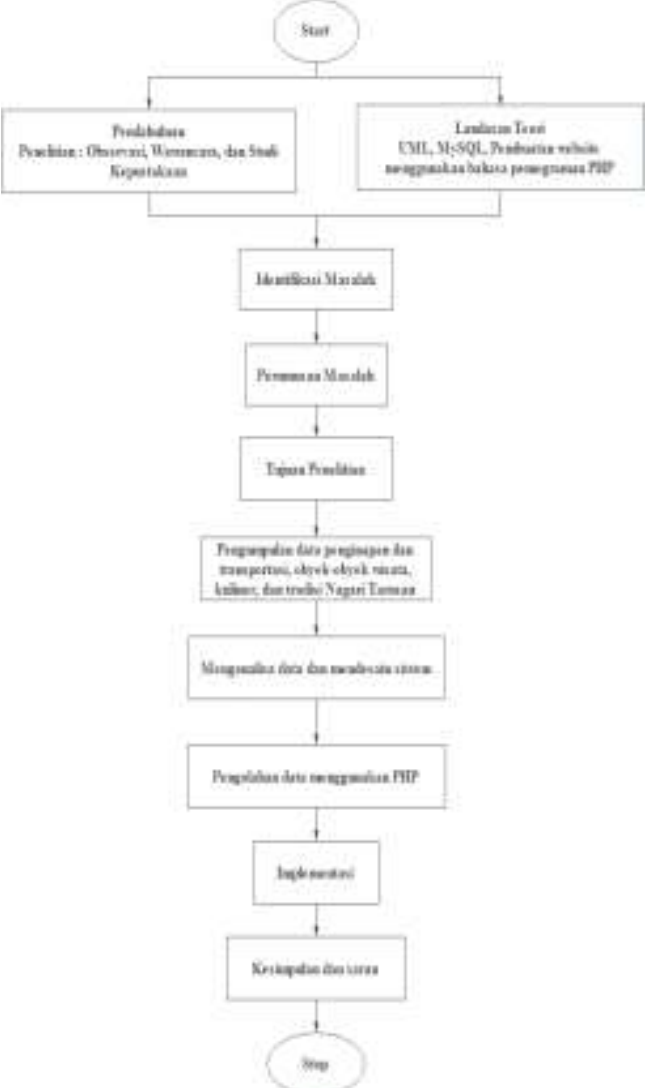

\section{Gambar 3.1 Kerangka Metodologi}

Tahapan-tahapan yang dilakukan dalam pembuatan kerangka metodoogi penelitian, yaitu :

\section{Desain Start}

Digunakan untuk memulai pekerjaan dari sebuah sistem. Tahapan-tahapan yang dilakukan, yaitu :

2. Pendahuluan

Pada tahapan ini berisi uraian yang dilakukan penulis saat melakukan penelitian, antara lain observasi, wawancara, dan studi kepustakaan.

3. Landasan Teori

Teori serta kajian yang relevan berdasarkan penelitian yang pernah dilakukan yang berhubungan dengan masalah yang akan di teliti.

4. Indentifikasi Masalah

Menganalisa masalah-masalah yang di temukan.

5. Perumusan Masalah

Tahapan ini menjelaskan cakupan masalah yang di teliti dan masalah itu di rumuskan dengan jelas. 
6. Tujuan Penelitian

Menjelaskan secara rinci yang akan di capai dalam masalah penelitian.

7. Pengumpulan Data

Pada tahapan ini, data penginapan dan transportasi, obyek-obyek wisata, kuliner, dan tradisi Nagari Tarusan akan di kumpulkan dan akan dilakukan penganalisaan data.

8. Menganalisa Data dan Mendesain Sistem Data-data yang sudah di dapat di analisa dan dilanjutkan ke tahapan mendesain sistem sesuai dengan kebutuhan. Data-data yang di dapat di olah dengan PHP.

9. Implementasi

Sistem yang sudah selesai di buat akan di coba untuk mengetahui kekurangan dan kelemahan dari sistem yang ada dan akan dilakukan perbaikan.

10. Desain Stop

Desain stop digunakan untuk mengakhiri pekerjaan dari sebuah sistem.

\section{ANALISA DAN DESAIN SISTEM \\ 4.1 Analisa Sistem}

Analisa sistem merupakan suatu istilah secara kolektif yang mendeskripsikan fase-fase awal pengembangan sistem dan teknik pemecahan masalah yang menguraikan bagianbagian dari komponen yang bekerja dan berinteraksi untuk mencapai suatu tujuan. Analisa sistem merupakan tahap yang paling awal dari pengembangan system. Dalam melakukan pengembangan sistem diperlukan data-data dari sistem lama sehingga dapat membantu serta menunjang dalam pengembangan sistem yang baru, dari sistem lama tersebut seorang analis harus mengetahui serta memahami secara keseluruhan dari sistem yang akan dirancang.

Data-data yang diperlukan berupa hal-hal yang berkaitan dengan sistem yang akan dibuat sehingga memudahkan dalam merancang sebuah sistem. Penelitian dilakukan bertujuan untuk melihat sistem yang lama dan dengan data itulah seorang analis bisa merancang serta membuat sebuah sistem baru. Seorang analis harus mengetahui kelemahan sistem yang lama dan sistem yang akan dirancang baik dari segi aktivitas sistem, efisiensi sistem serta hal-hal yang terkait dengan sistem tersebut.

\subsubsection{Evaluasi Sistem yang Sedang Berjalan}

Berdasarkan uraian yang ada pada analisa sistem pada Nagari Tarusan, serta hasil pengamatan dan penelitian yang dilakukan pada sistem informasi pariwisata, data obyekobyek pariwisata Nagari Tarusan masih kurang dan tidak adanya informasi tentang pemesanan paket wisata di dunia maya. Akses transportasi umum untuk menuju ke obyek-obyek pariwisata tersebut masih belum di kelola dengan baik sehingga wisatawan kesulitan.

4.1.2 Usulan Sistem Baru

Dari kendala tersebut maka dapat dilakukan pengembangan terhadap sistem sehingga menjadi sistem yang baru dan kendala yang dihadapi dapat teratasi, yaitu dengan melakukan :

1) Pembuatan website pemesanan paket wisata Nagari Tarusan.

2) Pembuatan interface dengan menggunakan bahasa pemrograman berbasis PHP.

\subsection{Desain Sistem}

Desain sistem merupakan adalah sebuah teknik pemecahan masalah yang saling melengkapi, yang merangkai kembali bagianbagian komponen menjadi sistem yang lengkap. Sistem ini melibatkan penambahan, penghapusan, dan perubahan-perubahan bagian relatif pada sistem awal.

\subsubsection{Use Case Diagram}

Use Case Diagram merupakan gambaran informasi dari suatu bagian ke bagian yang lain dimana informasi yang dihasilkan akan diproses secara komputerisasi. Untuk lebih jelas dapat dilihat pada gambar dibawah ini.

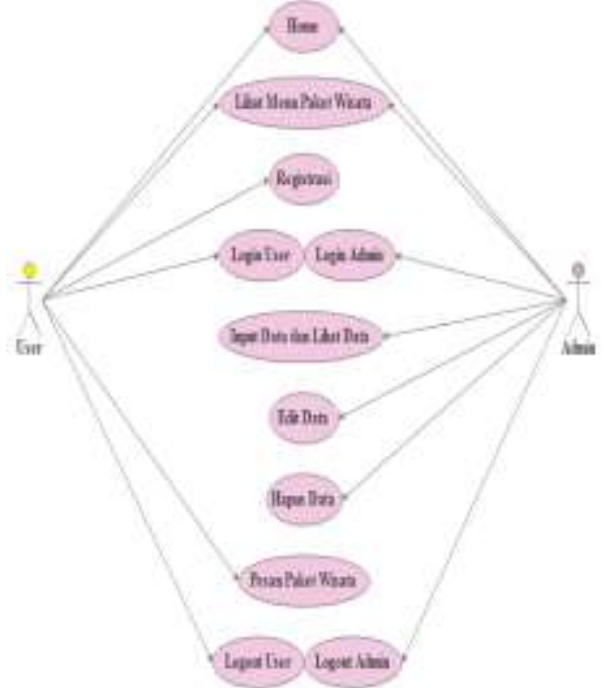

\section{Gambar 4.1 Use Case Diagram}

\subsubsection{Class Diagram}

Setelah memodelkan sistem utama dengan use case diagram, langkah selanjutnya penulis menganalisa class-class yang dapat 
disimpulkan dalam use case diagram. Class yang diperoleh dari hasil analisa disajikan dalam gambar berikut ini :

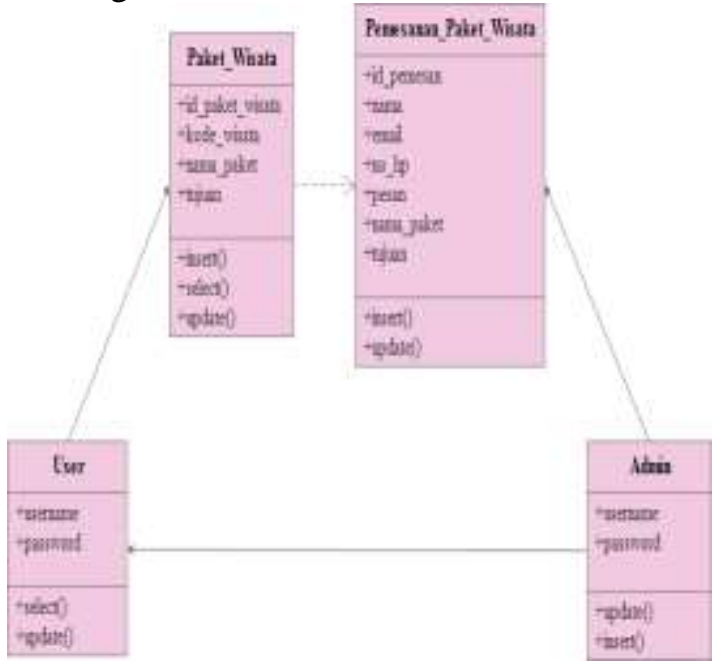

Gambar 4.2 Class Diagram

Agar lebih jelas lagi, keterangan dari class diagram adalah sebagai berikut :

1) Admin dapat menginput, mengedit dan menghapus data paket, harga ataupun tujuan wisata serta dapat melihat daftar paket wisata.

2) User dapat melihat menu paket wisata dan memesan paket wisata.

\subsubsection{Sequence Diagram}

Sequence diagram digunakan untuk menjabarkan aktifitas yang ada pada use case kepada level yang lebih detail, berikut gambar Sequence Diagram Pemesanan Paket Wisata

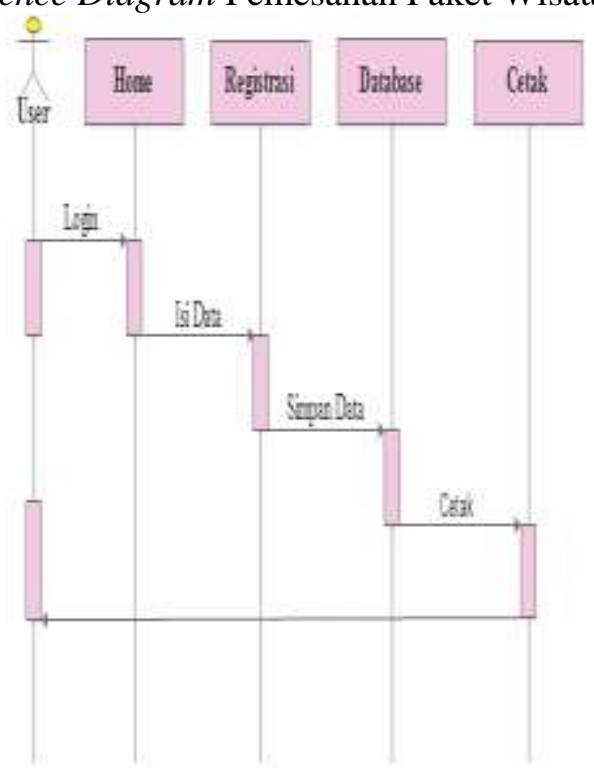

\section{Gambar 4.3 Sequence Diagram Pemesanan} Paket Wisata

Pada sequence diagram pemesanan paket wisata menerangkan bahwa aktor user melakukan login, melakukan registrasi dan mengisi data. Setelah semua data pemesanan paket wisata selesai, data di simpan ke database dan data pemesanan paket wisata di cetak.

Sequence Diagram Data Transaksi Paket Wisata

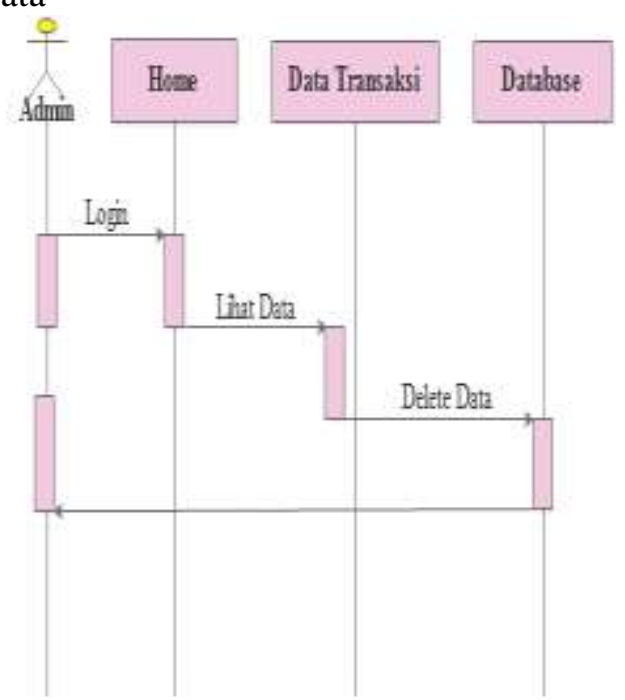

\section{Gambar 4.4 Sequence Diagram Data} Transaksi Paket Wisata

Pada sequence diagram data transaksi paket wisata menerangkan bahwa aktor admin melakukan login untuk melihat data transaksi paket wisata dan menghapus data transaksi yang ada di dalam database.

\subsection{Activity Diagram}

Activity diagram digunakan untuk memperlihatkan aliran dari suatu aktifitas ke aktifitas lainnya dalam suatu sistem. Berikut gambar activity diagram

Activity Diagram Pemesanan Paket Wisata

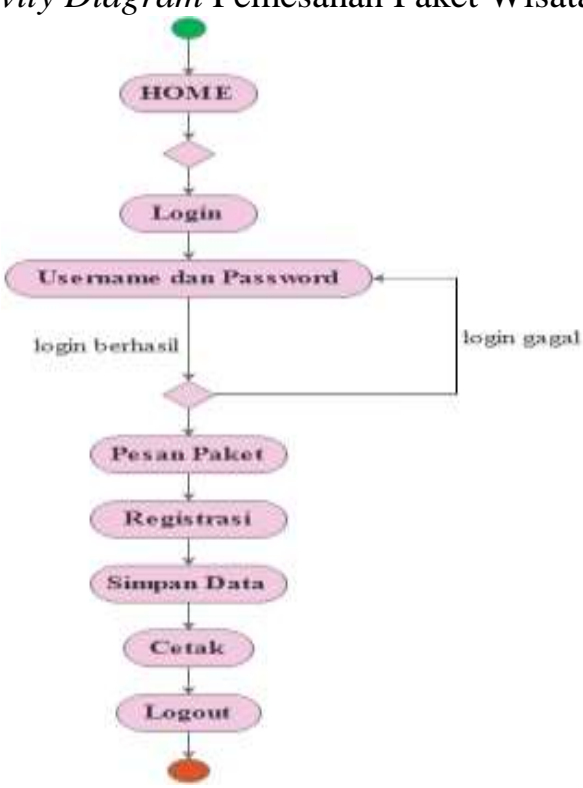

Gambar 4.5 Activity Diagram Pemesanan Paket Wisata 
Aktifitas user dimulai dengan field kunci yang berfungsi sebagai mengakses web, pada halaman ini pengunjung penghubung antar file. dapat mengakses halaman utama yang - Desain File Admin memberikan informasi tentang Nagari Tarusan. Selain itu juga ada form login untuk user untuk melakukan pemesanan paket wisata. Bagi user yang ingin memesan paket wisata, mereka harus melakukan registrasi sebagai member agar dapat memesan paket wisata yang ada.

Activity Diagram Data Transaksi Paket Wisata

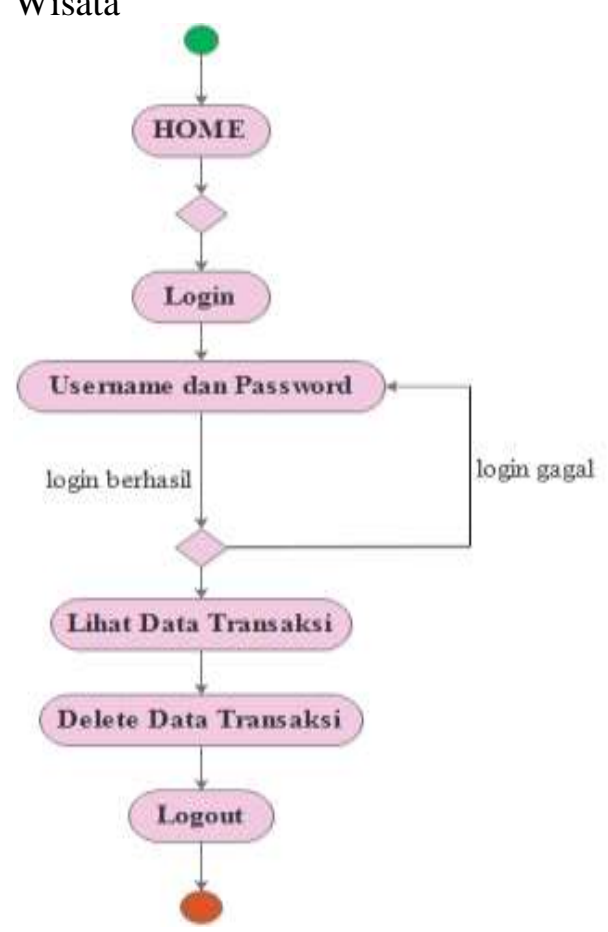

Nama Database : tarusan

Nama Table : admin

Primary Key : adminID

\section{Tabel 4.1 Desain File Admin}

\begin{tabular}{|c|l|l|l|l|}
\hline No & Field & Type & Size & Description \\
\hline 1 & adminID & Integer & 11 & AdminID \\
\hline 2 & username & Varchar & 15 & Username \\
\hline 3 & password & Varchar & 15 & Password \\
\hline
\end{tabular}

- Desain File Bank

Nama Database : tarusan

Nama Table : bank

Primary Key : : bankID

Tabel 4.2 Desain File Bank

\begin{tabular}{|l|l|l|l|l|}
\hline No & Field & Type & Size & Description \\
\hline 1 & bankID & Integer & 11 & BankID \\
\hline 2 & bankNama & Varchar & 15 & Nama Bank \\
\hline
\end{tabular}

- Desain File Identitas

Nama Database : tarusan

Nama Table : identitas

Primary Key: identitasID

Tabel 4.3 Desain File Identitas

\begin{tabular}{|c|l|l|l|l|}
\hline No & Field & Type & Size & Description \\
\hline 1 & identitasD & Integer & 11 & IdentitasID \\
\hline 2 & jenisID & Varchar & 15 & JenisID \\
\hline
\end{tabular}

\section{Gambar 4.6 Activity Diagram Data Transaksi Paket Wisata}

Aktifitas admin dimulai dengan mengakses web, sebelum admin melihat data transaksi paket wisata, admin terlebih dahulu harus login. Setelah itu admin bisa melihat data dan menghapus data transaksi yang ada.

\subsection{Desain File}

File berfungsi untuk menyimpan dan mengorganisasi data, file-file tersebut terdiri dari beberapa record, record ini terdiri dari beberapa field, setiap record akan menampung data yang akan diproses menghasilkan informasi. Database yang digunakan adalah MySQL, yang mana MySQL merupakan Relational Database Management Sistem (RDBMS), di mana setiap orang bebas untuk menggunakan MySQL.

Rancangan program untuk pemesanan paket wisata Nagari Tarusan terdiri atas beberapa file. Setiap file akan mempunyai

- Desain File Jadwal

Nama Database : tarusan

Nama Table : jadwal

Primary Key: jadwalID

Tabel 4.4 Desain File Jadwal

\begin{tabular}{|l|l|l|l|l|}
\hline No & Field & Type & Size & Description \\
\hline 1 & jadwalID & Integer & 11 & JadwalID \\
\hline 2 & paketID & Integer & 11 & PaketID \\
\hline 3 & tujuanID & Integer & 11 & Tujuan \\
\hline 4 & tujuanID1 & Integer & 11 & TujuanID1 \\
\hline 5 & Harga & Varchar & 20 & Harga \\
\hline 6 & Jam & Time & & Jam \\
\hline
\end{tabular}

- Desain File Jumlah

Nama Database : tarusan

Nama Table : jumlah

Primary Key: jumlahID

Tabel 4.5 Desain File Jumlah

\begin{tabular}{|l|l|l|l|l|}
\hline No & Field & Type & Size & Description \\
\hline 1 & jumlahID & Integer & 11 & JumlahID \\
\hline 2 & jumlahNama & Double & & Jumlah Nama \\
\hline
\end{tabular}


- Desain File Paket

Nama Database : tarusan

Nama Table : paket

Primary Key: paketID

Tabel 4.6 Desain File Paket

\begin{tabular}{|l|l|l|l|l|}
\hline No & Field & Type & Size & Description \\
\hline 1 & paketID & Integer & 11 & PaketID \\
\hline 2 & paketNama & Integer & 11 & Nama Paket \\
\hline
\end{tabular}

- Desain File Pembayaran

Nama Database : tarusan

Nama Table : pembayaran

Primary Key: pembayaranID

Tabel 4.7 Desain File Pembayaran

\begin{tabular}{|l|l|l|l|l|}
\hline No & Field & Type & Size & Description \\
\hline 1 & pembayaranID & Integer & 11 & PembayaranID \\
\hline 2 & $\begin{array}{l}\text { jenisPembayar } \\
\text { an }\end{array}$ & Varchar & 11 & $\begin{array}{l}\text { Jenis } \\
\text { Pembayaran }\end{array}$ \\
\hline
\end{tabular}

- Desain File Reservasi

Nama Database : tarusan

Nama Table : reservasi

Primary Key: reservasiID

Tabel 4.8 Desain File Reservasi

\begin{tabular}{|l|l|l|l|l|}
\hline No & Field & Type & Size & Description \\
\hline 1 & reservasiID & Integer & 11 & ReservasiID \\
\hline 2 & Nama & Varchar & 25 & Nama \\
\hline 3 & no_identitas & Varchar & 15 & No_Identitas \\
\hline 4 & identitasID & Integer & 11 & IdentitasID \\
\hline 5 & no_telp & Varchar & 15 & No_Telp \\
\hline 6 & email & Varchar & 25 & Email \\
\hline 7 & jadwalID & Integer & 11 & JadwalID \\
\hline 8 & paketID & Integer & 11 & PaketID \\
\hline 9 & tujuanID & Integer & 11 & TujuanID \\
\hline 10 & tujuanID1 & Integer & 11 & TujuanID1 \\
\hline 11 & $\begin{array}{l}\text { pembayaran } \\
\text { ID }\end{array}$ & Integer & 11 & $\begin{array}{l}\text { PembayaranI } \\
\text { D }\end{array}$ \\
\hline 12 & pemilik & Varchar & 15 & Pemilik \\
\hline 13 & bankID & Integer & 11 & BankID \\
\hline 14 & rekening & Varchar & 15 & Rekening \\
\hline 15 & jumlahID & Integer & 11 & JumlahID \\
\hline 16 & $\begin{array}{l}\text { tanggal_ber } \\
\text { angkat }\end{array}$ & Date & & $\begin{array}{l}\text { Tanggal } \\
\text { Berangkat }\end{array}$ \\
\hline
\end{tabular}

\begin{tabular}{|l|l|l|l|l|}
\hline No & Field & Type & Size & Description \\
\hline 1 & tujuanID1 & Integer & 11 & TujuanID1 \\
\hline 2 & tujuanNama1 & Varchar & 40 & $\begin{array}{l}\text { Nama } \\
\text { Tujuan1 }\end{array}$ \\
\hline
\end{tabular}

- Desain File User

Nama Database : tarusan

Nama Table : user

Primary Key : : userID

\section{Tabel 4.13 Desain File User}

\begin{tabular}{|l|l|l|l|l|}
\hline No & Field & Type & Size & Description \\
\hline 1 & userID & Integer & 11 & UserID \\
\hline 2 & Username & Varchar & 15 & Username \\
\hline 3 & Password & Varchar & 15 & Password \\
\hline 4 & accesLevel & Varchar & 15 & Level Acces \\
\hline
\end{tabular}

- Desain File Testi

Nama Database : tarusan

Nama Table : testi

Primary Key: testiID

Tabel 4.9 Desain File Testi

\begin{tabular}{|l|l|l|l|l|}
\hline No & Field & Type & Size & Description \\
\hline 1 & testiID & Integer & 11 & TestiID \\
\hline 2 & username & Varchar & 15 & Username \\
\hline 3 & pesan & Varchar & 150 & Pesan \\
\hline
\end{tabular}




\section{IMPLEMENTASI SISTEM \\ 5.1 Implementasi Sistem}

Implementasi sistem adalah suatu prosedur yang di lakukan pada tahap sistem dalam dokumen yang disetujui dan menguji, kemudian menginstal dan menggunakan program yang di buat.

Tujuan Implementasi sistem adalah sebagai berikut :

a. Memperhitungkan bahwa sistem yang sudah dibuat sesuai dengan kebutuhan.

b. Menyelesaikan desain sistem yang ada dalam dokumen sistem yang disetujui.

c. Mengkonversikan sistem lama kesistem yang baru.

d. Mendokumentasikan program serta prosedur-prosedur yang diperlukan oleh dokumen desain sistem yang di uji.

Untuk merancang dan mengimplementasikan sistem yang dirancang di perlukan sebuah alat berupa komputer sebagai media yang dapat membantu dalam pengaplikasikannya. Pada komputer terdapat tiga komponen penting seperti hardware, software dan brainware.

\subsection{Desain Database}

Mendesain database pada bab ini menggunakan XAMPP yang di dalamnya terdapat PHP MyAdmin, yang di mulai dari menginstal software tersebut serta mengikuti langkah-langkah dalam menginstal hingga selesai. Setelah proses instalasi selesai, aktifkan XAMPP dan mengaktifkan Apache dan Mysql. Dianjutkan dengan membuka browser Mozilla Firefox, ketikan http://localhost/XAMPP. Selanjutnya pada tool XAMPP piih PHP MyAdmin, maka kita akan masuk pada tampilan PHP MyAdmin. Setelah berada di menu PHP MyAdmin, selanjutnya dibuat database dengan cara memilih menu Create New Database dan diberi nama tarusan.

Selanjutnya kita membuat tabel, tabel yang dibutuhkan pada database terdiri dari tabel admin, bank, identitas, jadwal, jumlah, paket, pembayaran, reservasi, testi, trayek, tujuan, tujuan1, dan users seperti gambar di bawah ini :

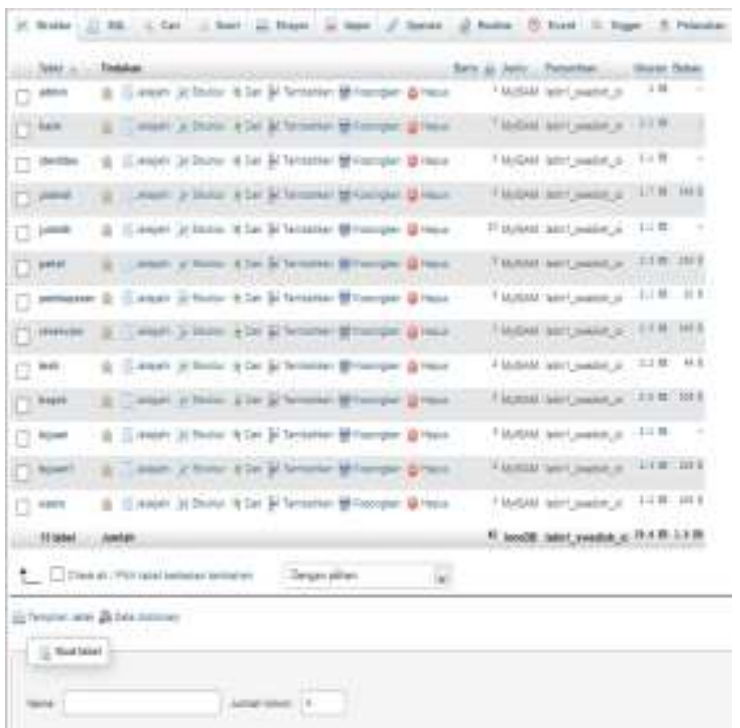

Gambar 5. 1 Tabel Pada Database

\section{Pengujian Sistem}

Pengujian sistem dilakukan untuk menguji hubungan antara program aplikasi yang dibuat dengan elemen yang lain dalam sistem informasi. Adapun tujuan dari pengujian sistem ini adalah untuk memastikan semua elemen sistem sudah terhubung dengan baik. Pada pengujian sistem ini akan dilihat perbedaan antara sistem yang lama dengan sistem yang baru. Berikut merupakan penjelasan beserta gambar tentang Sistem Informasi Pemesanan Paket Wisata Nagari Tarusan Kabupaten Pesisir Selatan.

\subsubsection{Menu Utama}

Menu utama adalah menu awal yang ditampilkan ketika pertama kali kita mengakses website.

\subsubsection{Home}

Pada bagian home ini menampilkan profil dari Nagari Tarusan dan menu yang terdapat pada program aplikasi, serperti : menu pariwisata, menu paket wisata, menu cara pemesananan paket wisata, dan contact.

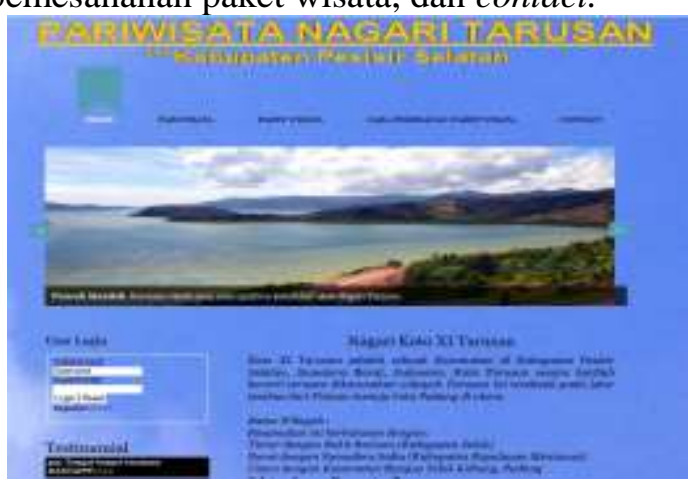

Gambar 5.2 Tampilan Home 


\subsubsection{Wisata Alam}

Pada bagian wisata alam ini menampilkan obyek-obyek wisata alam yang ada pada Nagari Tarusan.

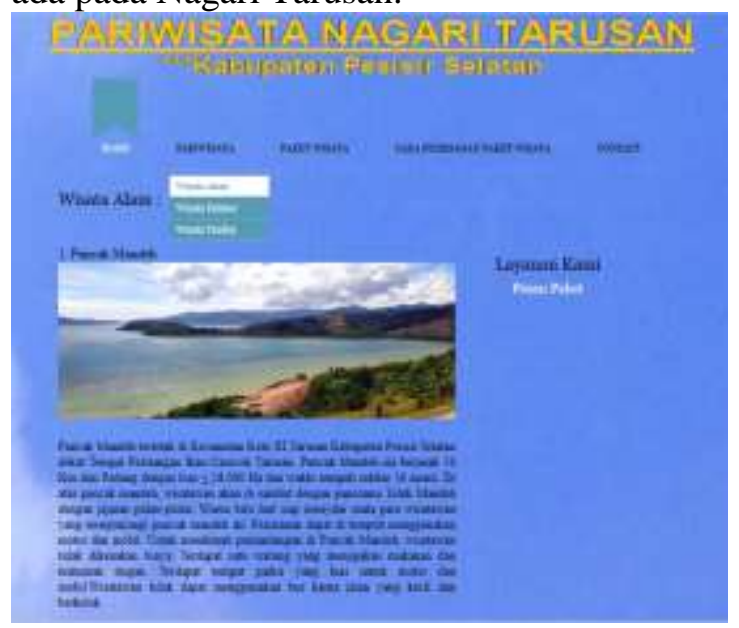

Gambar 5.3 Menu Wisata Alam

\subsubsection{Wisata Kuliner}

Pada bagian wisata kuliner ini menampilkan kuliner yang ada pada Nagari Tarusan.

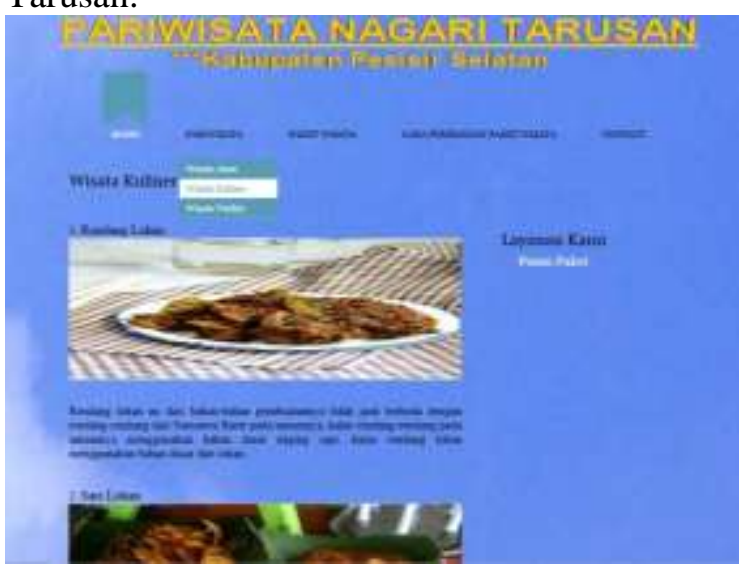

Gambar 5.4 Menu Wisata Kuliner

\subsubsection{Wisata Tradisi}

Pada bagian wisata tradisi ini menampilkan tradisi yang ada pada Nagari Tarusan.

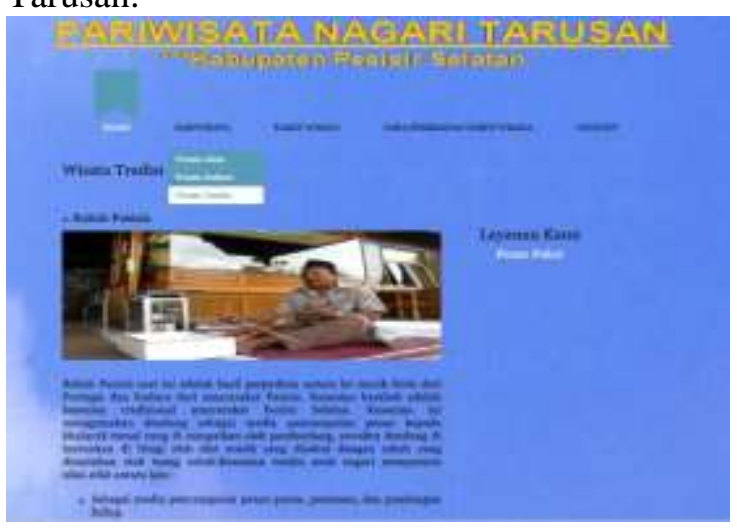

Gambar 5.5 Menu Wisata Tradisi

\subsubsection{Cara Pemesanan Paket Wisata}

Pada bagian cara pemesanan paket wisata ini menampilkan cara-cara pemesanan paket wisata.

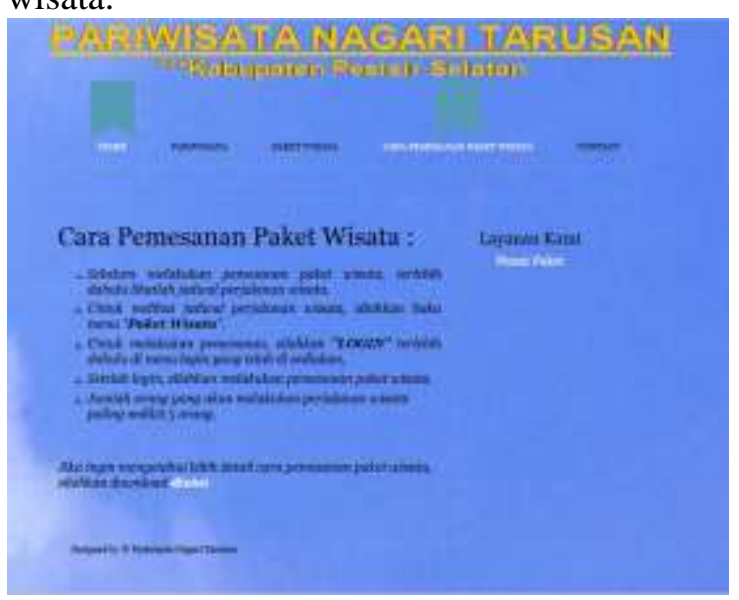

\section{Gambar 5.6 Menu Cara Pemesanan Paket} Wisata

\subsubsection{Contact}

Pada bagian contact ini semua yang mengakses website pariwisata Nagari Tarusan dapat menghubungi nomor hp yang ada atau berkirim email ke email yang ada untuk bertanya tentang pemesanan paket wisata.

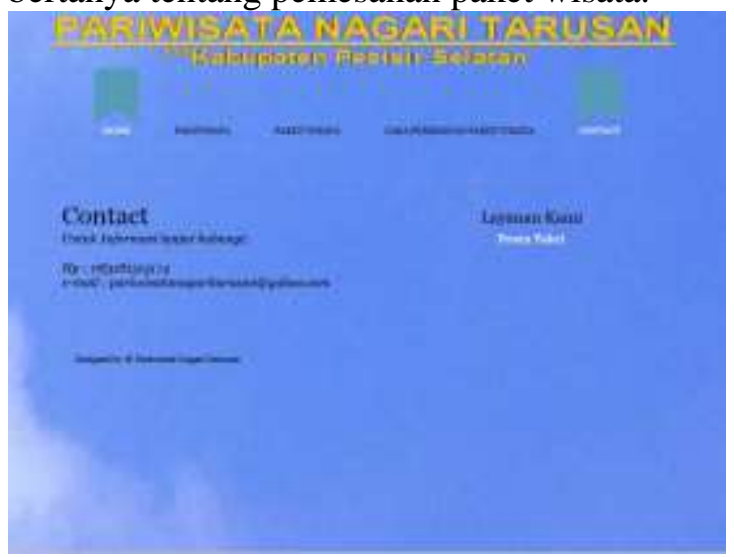

Gambar 5.7 Menu Contact

\subsubsection{Register Users}

Pada bagian register users ini semua yang mengakses website pariwisata Nagari Tarusan harus mendaftar untuk melakukan pemesanan paket wisata.

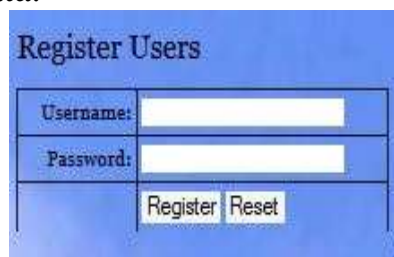

\section{Gambar 5.8 Menu Register Users}

\subsubsection{Jadwal Perjalanan Wisata}

Pada bagian jadwal perjalanan wisata ini semua yang mengakses website pariwisata 
Nagari Tarusan dapat memesan paket wisata yang ada.

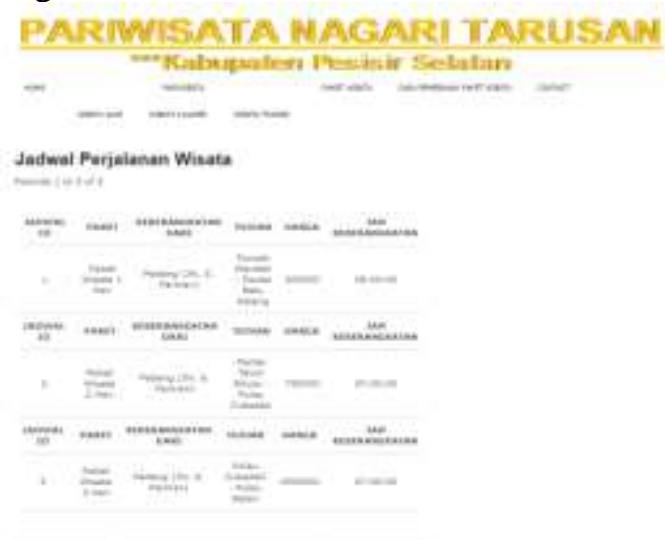

\section{Gambar 5.9 Jadwal Perjalanan Wisata}

\subsubsection{Input Data Pemesanan Paket Wisata}

Pada bagian input data pemesanan paket wisata ini semua yang mengakses website pariwisata Nagari Tarusan yang sudah login dapat menginputkan data diri untuk melakukan pemesanan paket wisata.

Pemesanan Paket Wisata

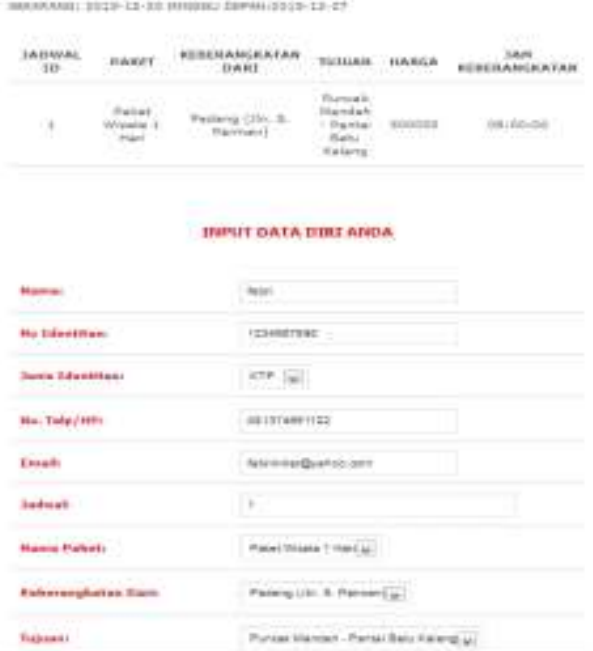

Gambar 5.10 Input Data Pemesanan Paket

\subsubsection{Bukti Pemesanan Paket Wisata}

Pada bagian bukti pemesanan paket wisata ini menampilkan data diri yang sudah berhasil di inputkan pada saat melakukan pemesanan.

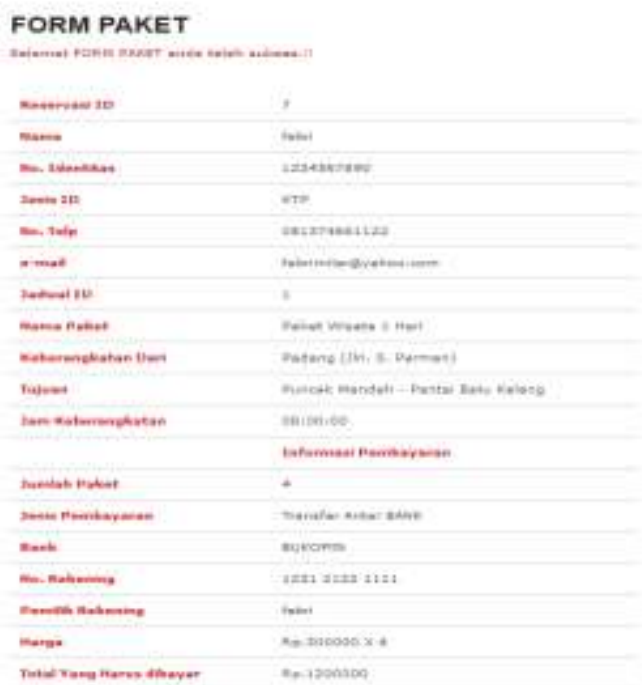

Gambar 5.11 Bukti Pemesanan Paket

\subsubsection{Admin Login}

Pada bagian admin login ini merupakan halaman utama dimana admin mengakses kedalam system dengan memasukan username dan password sehingga sistem dapat membaca apakah user sebagai admin.

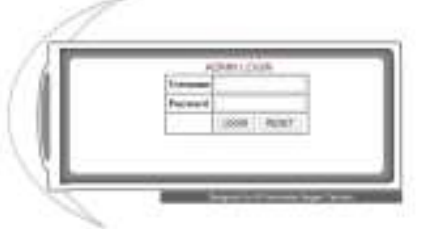

Gambar 5.12 Admin Login

\subsubsection{Edit dan Delete Data}

Pada bagian Edit dan Delete Data ini admin dapat mengedit dan mendelete data yang ada.

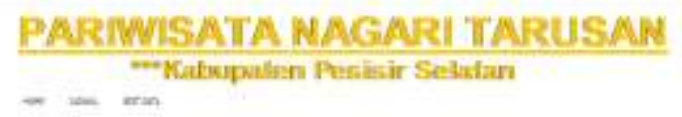

\section{EOIT \& DELETE DATA}

thinis

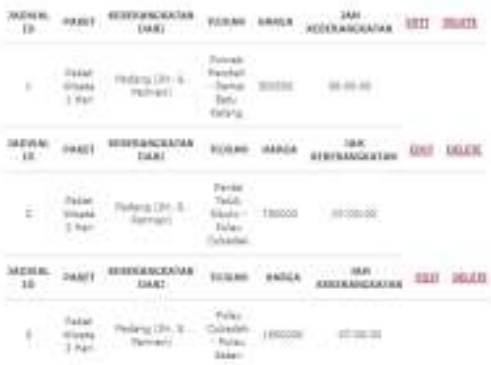

Gambar 5.13 Edit dan Delete Data 


\subsubsection{Transaksi Paket Wisata}

Pada bagian Transaksi Paket Wisata ini admin dapat melihat dan menghapus transaksi paket wisata data yang ada.

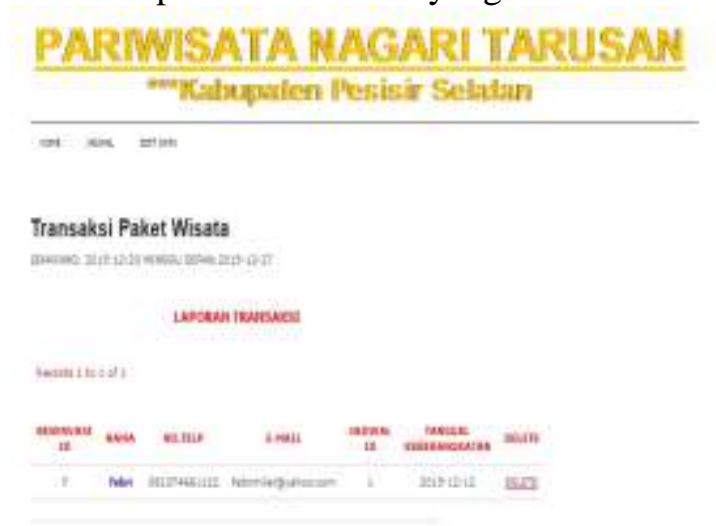

Gambar 5.14 Transaksi Paket Wisata

\section{PENUTUP}

\section{Kesimpulan}

Berdasarkan hasil penelitian pada Nagari Tarusan, maka penulis mengambil kesimpulan, sebagai berikut : Website sistem informasi pemesanan paket wisata pada Nagari Tarusan akan memberikan kemudahan untuk mendapatkan informasi bagi masyarakat yang ingin mengetahui tetang pemesanan paket paket wisata.

\section{DAFTAR KEPUSTAKAAN}

Ir. Yusti, Irwan, M. Kom, Bahan Ajar Analisa Dan Perancangan Berorientasi Objek, STTIND Padang, Padang, 2012

Nofriadiman, ST, M.kom, dkk, Buku Panduan Penulisan Dan Ujian Skripsi STTIND Padang, Padang 2013

Nugroho, Adi, Rekayasa Perangkat Lunak Menggunakan UML \& Java, Andi Offset, Yogyakarta, 2010

Sibero, Alexander F.K, "Kitab Suci Web Programing", Mediakom, Jakarta, 2011

Simarmata, Janner, Rekayasa Web, Andi, Yogyakarta, 2010

Sutabri, Tata, Konsep Sistem Informasi, Andi Offset, Yogyakarta, 2012

http://digilib.uinsby.ac.id/363/2/Bab\% 201.p df/Pariwisata, di akses pada 30 November 2015

https://id.wikipedia.org/wiki/Pariwisata, di akses pada 30 November 2015 